Journal of Environmental Sciences (JES)

Institute of Environmental Studies and Research, Ain Shams University

Mahmoud, Al-Shaymaa et al.

\title{
USING OF EXTRACTED MAGNESIUM OXIDE FROM CATIONIC RESIN REGENERATION WASTEWATER TO BE USED IN THE TREATMENT OF HEAVY FUEL OIL IN THE STEAM BOILERS IN POWER PLANTS
}

\author{
Al-Shimaa M. Mahmoud ${ }^{(1)}$; Mahmoud A. Hewehy ${ }^{(2)}$ \\ Ashraf I. Hafez ${ }^{(3)}$ \\ 1) Egyptian Electrical Production Company 2) Institute of Environmental \\ Studies and Research, Ain Shams University 3) Egyptian Electricity Holding \\ Company
}

\begin{abstract}
Magnesium oxide is one of the most products that used as fuel additive in the treatment of heavy fuel oil. It has a good efficiency in the reduction of the bad effects produced from burning heavy fuel oil. In this work, extraction of magnesium oxide from wastewater of cation exchange regeneration unit was studied. The extracted magnesium oxide was suspended in a solution of gelatin as a suspension agent. Different doses of suspended magnesium oxide were added to heavy fuel oil. The optimum dose for maximum reduction of the free sulfuric acid (acidity) exists in the combustion products was determine, also emission produced from burning treated and untreated heavy fuel oil were investigated. By this treatment, the values of sulfur, sodium and vanadium in the fuel were reduced, while physical properties of fuel were approximately stable. The amount of reduction of some pollutants between treated and untreated heavy fuel oil was calculated. However, sulfur in heavy fuel oil was reduced from 1.6 to $1.2 \mathrm{ppm}$ with a percent reduction of $25 \%$. The vanadium was reduced from 48 to $37 \mathrm{ppm}$ with percentage reduction of $9.1 \%$ and sodium was reduced from 84 to $74 \mathrm{ppm}$ with a percentage reduction of $11.9 \%$, also the value of free sulfuric acid is reduced from 67 to $50 \mathrm{ppm}$ with
\end{abstract}


Journal of Environmental Sciences (JES)

Institute of Environmental Studies and Research, Ain Shams University

Mahmoud, Al-Shaymaa et al.

percentage reduction of $28 \%$ and this is an indication for the reduction of $\mathrm{SO}_{\mathrm{X}}$ emission.

Key words: Emission, Fuel additives, magnesium oxide, sodium, vanadium, Sulphur.

\section{INTRODUCTION}

There are many techniques performed for emissions reduction from oil fired installations like operating procedures, fuel selection, design and installation, combustion modifications, new combustion procedures, and fuel additives. Fuel additives have been one of the most prolific innovations of liquid engineering as well as material science which can alter fuels burning rate, increase surface area, and prevent corrosive effects. It gives also natural fuel sources additional properties (Emara et al., 2016). The flue gas from combustion of the fossil fuels is discharged to the air. This gas contains carbon dioxide and water vapor, as well as other substances such as nitrogen oxides $\left(\mathrm{NO}_{\mathrm{X}}\right)$, sulfur oxides $\left(\mathrm{SO}_{\mathrm{X}}\right)$ and carbon monoxide, for coal and heavy fuel oil fired plants, fly ash as solid waste (Khalil et al., 2020) . Oil-Fired Steam Power Plant using fossil fuels has destructive effects on environment. Emission of pollutants such as SOx produced by burning fuel oil and coal in power plants has bad effects on public health, water and forest ecosystem, due to the acidification of soil and lakes. The emissions produced from the burning of heavy fuel oil can be minimized according to some factor such as:

- Fuel switching from heavy oil to natural gas.

- Sulfur content reduction of heavy oil fuel. 
- Installation of Flue Gas Desulfurization (FGD) systems.

- Using fuel additives. (EIA, 2013).

- Fuel additives are chemicals, which alter the combustion parameters including:

a) Provide boiler cleanliness.

b) High temperature vanadium corrosion protection.

c) Prevention of loss of operating capacity by maintaining design steam temperatures.

d) Cold end (air heater) corrosion protection.

e) Reduction of stack emissions from hydrocarbon particulate matter and $\mathrm{SO}_{3}$.

$\mathrm{MgO}-$ based additives are considered as the most promising additives that can minimize sodium and vanadium related fouling problems in utility boilers. Additives that fall into this category include $\mathrm{MgO}, \mathrm{Mg}(\mathrm{OH}) 2$ $\mathrm{MgCO}_{3}$, and dolomite (Stas , 2007). The additives have been used in recovery boilers to minimize deposit buildup on superheated and generating bank tubes. In addition, the additive treatments are intended to prolong the boiler operating time between washouts. In order to minimize fouling problems, the additives are usually continuously injected into boilers during operation. The additives were claimed to work either by forming a thin coating on the tube surface to prevent deposits from building up, prevent the formation of blocking layer between deposits and the tube surface and facilitating deposit 
Journal of Environmental Sciences (JES)

Institute of Environmental Studies and Research, Ain Shams University

Mahmoud, Al-Shaymaa et al.

removal by soot blowers (Vitolo, 2000). However, these claims have never been verified nor supported by scientific evidence. In addition, the additives have helped to alleviate fouling problems in their boilers tubs (Tsuboi , 1991). On the other hand, demineralization of water or deionization of water process is the removal of essentially all inorganic salts by ion exchange in the water treatment processes. In this water treatment process, strong acid cation resin in the hydrogen form replaced cations into their corresponding acids, and strong base anion resin in the hydroxide form replaced anions (Sanciolo, et al 2010). The wastewater produced from regeneration process has a higher amount of salts especially calcium and magnesium salts ( Peter, 2010). This wastewater is like brine solution (saline solution). Previous studies have shown that salts in brine can be recovered and purified as commercial products. Salts have been recovered from salty lakes and sea water (Kilic, 2005 , Drioli et al , 2004 and Himawan, 2006), the maximum percentage recovery of calcium salts obtained at $\mathrm{pH}$ value between10-11, while magnesium salts was between11-12.( Khalil et al , 2014), Magnesium oxide has numerous applications in both agricultural and industrial fields. In industry magnesium oxide is useful as a boiler feed additive and is one of the primary reactant materials in many chemical process reactions, such as acid neutralization, cation replacement, and hydration, for many of these uses and application it would be advantageous to provide a high concentration aqueous magnesium oxide suspension to facilitate handling and ease of incorporation into a resultant product or reaction, or for use as a direct application for boiler $1 \angle U$ 
Journal of Environmental Sciences (JES)

Institute of Environmental Studies and Research, Ain Shams University

Mahmoud, Al-Shaymaa et al.

feed additives, The insoluble magnesium oxide, frequently settles and/or causes formation of an immobile gel-like mixture, particularly at concentrations above about six percent. So it requires a suspension stabilization, the xanthan gum is said to provide suspension stabilization ( Van de Wale, 1989 ), also gelatin is an excellent suspension agent (Sylvester et al, 2014), in this work extracted magnesium oxide was suspended in gelatin solution and it showed excellent suspension stabilization for magnesium oxide. The suspended $\mathrm{MgO}$ was used as heavy fuel additive to improve its properties and preventing combustion problems.

\section{MATERIALS AND METHODS}

Chemicals: Sodium hydroxide and potassium hydroxide were supplied by (NC-0874 Science Company). Commercial gelatin from local market, ammonia was supplied by UN 2672.

All chemicals used in the analysis of water and fuel were of laboratory grades.

\section{Analysis:}

- Emission were determined by using land combustion analyzer model 6500

- Sulphur was determined by using LECO Tru-Spec analyzer.

- Sodium and vanadium was determined by using atomic absorption spectrophotometer model Thermo SOLAAR S4.

- Density was determined according to ASTM D4052.

- Kinematic viscosity was determined according to ASTM D7042. 
Journal of Environmental Sciences (JES)

Institute of Environmental Studies and Research, Ain Shams University

Mahmoud, Al-Shaymaa et al.

- Water content was determined according to ASTM D95.

- Water and sediments was determined according to ASTM D4007.

- Ash content was determined according to ASTM D482.

- Carbon residue was determined according to ASTM 4530.

- Asphaltenes was determined according to ASTM D6560.

- X-ray analysis was determined by using energy dispersive X-ray model FEI INSPECT S50.

- $\mathrm{PH}$ was determined by HACH sension3 PH Meter

\section{Preparation of magnesium oxide as fuel additive:}

\section{Precipitation of Magnesium Salts from Wastewater of Demineralization}

Plant: The main ingredients of cation regeneration wastewater are calcium and magnesium ions. $\mathrm{pH}$ plays an important role in the precipitation of calcium and magnesium salts from this water, thus ammonium \& sodium hydroxide which have the higher $\mathrm{pH}$ value can provide an excellent condition for precipitation of calcium and magnesium salts when added to cation regeneration wastewater. The calcium salts was firstly precipitated at $\mathrm{pH}$ of 10.5 by the addition of ammonium hydroxide. The increasing of $(\mathrm{pH})$ by further addition leads to increase the precipitation level of magnesium salts. The magnesium salts were fully precipitated at $\mathrm{pH}$ of 11.5 and more.

Figure (1) shows the typical photograph of the extracted magnesium salt. 


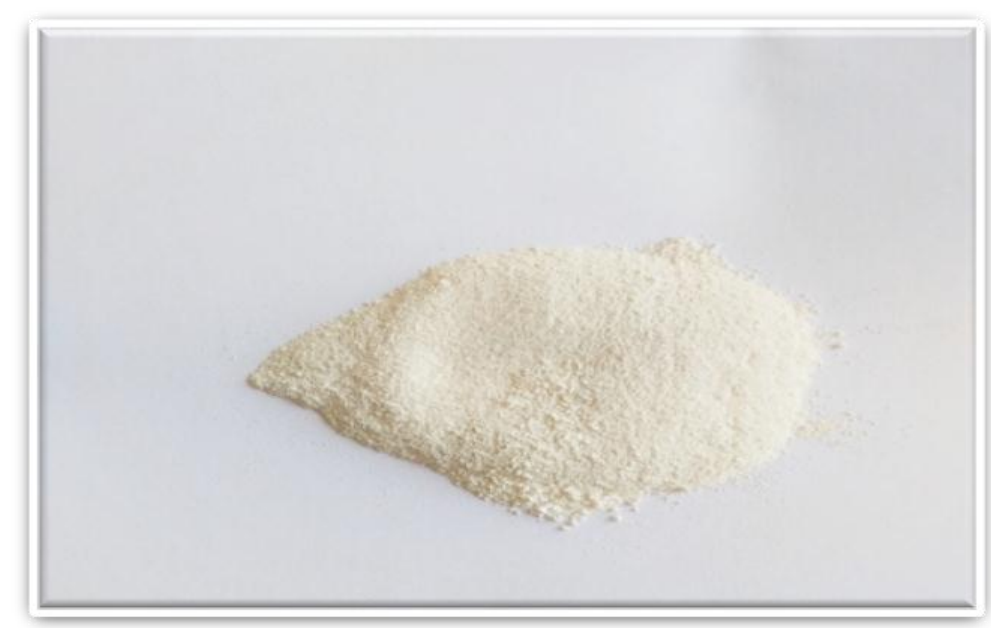

Figure (1): Typical photograph of the extracted magnesium salt

The extracted magnesium salt was put in a muffle furnace at $650{ }^{\circ} \mathrm{C}$ for 4 hours to convert magnesium carbonate and hydroxide to magnesium oxide (Khalil et al, 2014).

Preparation of magnesium oxide suspension solution: Gelatin is an excellent suspended agent (Sylvester et al, 2014), thus it used for the preparation of magnesium oxide suspension. A Solution of $10 \%$ gelatin in demineralized water was prepared. 2,4,6,8 and $10 \mathrm{gm}$ of extracted salts were added to $100 \mathrm{ml}$ of the aforementioned solution to prepare 2,4,6,8 and $10 \%$ suspended solutions of magnesium oxide.

Determination of rate of precipitation of magnesium oxide in suspended solution: The rate of precipitation of magnesium oxide in suspended solution was determined by using graduated cylinder. The distance of precipitation 
Journal of Environmental Sciences (JES)

Institute of Environmental Studies and Research, Ain Shams University

Mahmoud, Al-Shaymaa et al.

with time was measured visually (Sylvester et al, 2014).

Treatment of heavy fuel oil with prepared magnesium oxide suspension solution: Different concentrations of $\mathrm{MgO}(0,0.03,0.04,0.06$ and $0.08 \mathrm{mg})$ were added to one liter of heavy fuel oil. These mixtures were stirred very well at $80{ }^{\circ} \mathrm{C}$ for $1 / 2 \mathrm{~h}$. The mixtures were prepared to determine acidity as $\mathrm{H}_{2} \mathrm{SO}_{4}, \mathrm{pH}$ of combustion products, $\mathrm{S}, \mathrm{V}, \mathrm{Na}$ and other physical properties.

Determination of $\mathrm{pH}$ of combustion products produced from burning treated heavy fuel oil: The heavy fuel oils with $\mathrm{MgO}$ were burned. The remaining ash was collected as combustion product. One gram of these products for each concentration of $\mathrm{MgO}$ was dissolved in $100 \mathrm{ml}$ deionized water then the $\mathrm{pH}$ of this solution was determined.

Determination of free sulfuric acid in combustion products produced from burning treated heavy fuel oil: The heavy fuel oils with $\mathrm{MgO}$ were burned. The remaining ash was collected as combustion product. One gram of these products for each concentration of $\mathrm{MgO}$ was dissolved in $100 \mathrm{ml}$ deionized water then filtrated and titrated with $\mathrm{KOH}$ (ASTM D664).

\section{RESULTS AND DISCUSSIN}

\section{Extraction of Magnesium Salts from Waste Water of Regeneration} Process in demineralization Plant: Table (1) shows the chemical analysis of cation regeneration wastewater. 
Mahmoud, Al-Shaymaa et al.

Table (1): Chemical analysis of cation regeneration wastewater

\begin{tabular}{|c|c|}
\hline Analysis & Value \\
\hline \hline $\mathrm{pH}$ & 6.61 \\
\hline Total hardness $\mathrm{mg} / \mathrm{l}\left(\mathrm{as} \mathrm{CaCO}_{3}\right)$ & 3000 \\
\hline Calcium hardness $\mathrm{mg} / \mathrm{l}\left(\mathrm{as} \mathrm{CaCO}_{3}\right)$ & 1750 \\
\hline Magnesium hardness $\mathrm{mg} / \mathrm{l}\left(\mathrm{as} \mathrm{CaCO}_{3}\right)$ & 1250 \\
\hline Sodium $\mathrm{mg} / \mathrm{l}$ as Na & 870 \\
\hline Iron $\mathrm{mg} / \mathrm{l}$ & 29 \\
\hline
\end{tabular}

X-ray analysis of extracted salts: The extracted salts at $\mathrm{pH}$ (10.5) and (11.5) were analyzed by using; Energy Dispersive X-ray System.

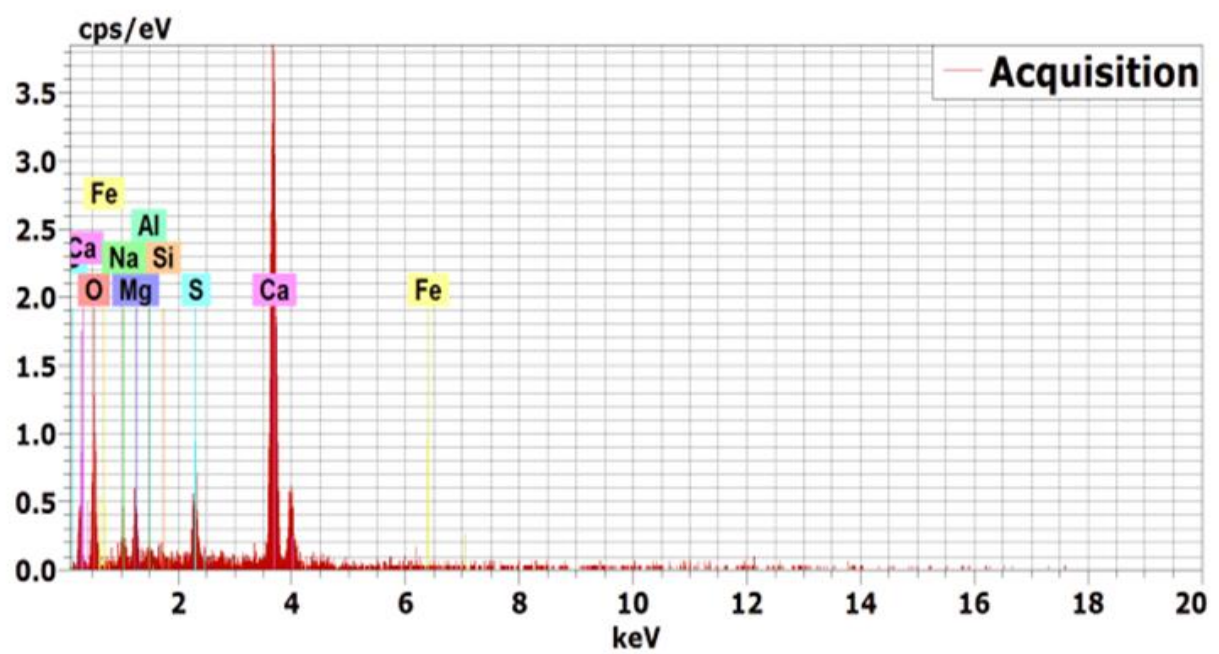

Figure (2): X-ray of extracted salt at $\mathrm{pH} 10.5$ 


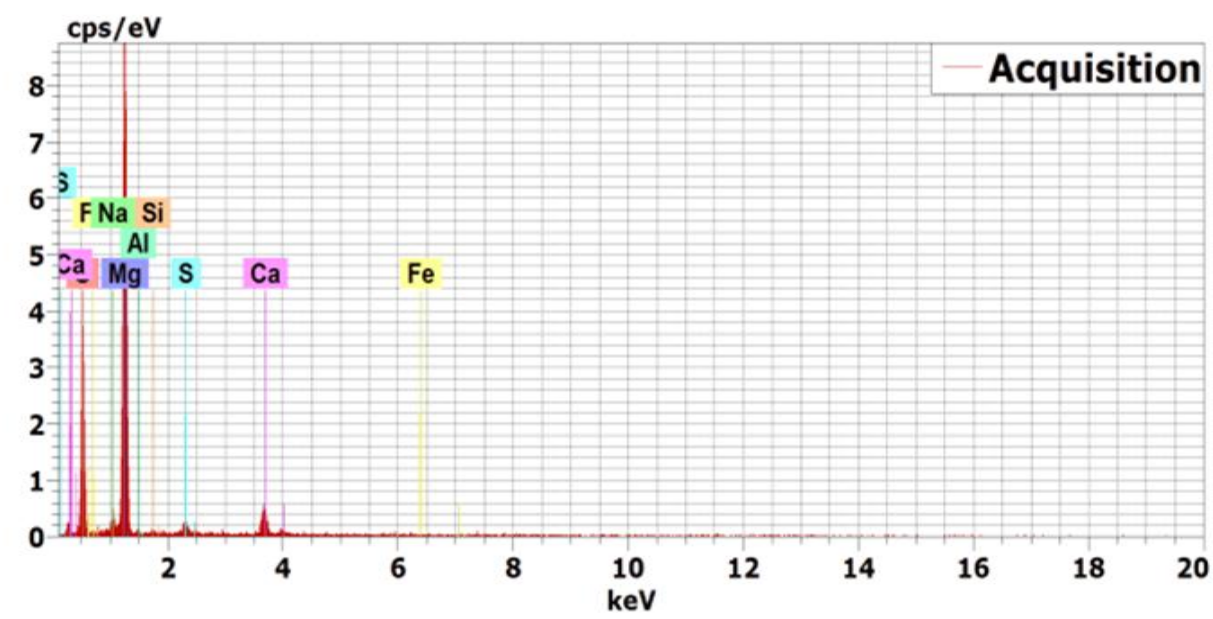

Figure (3): Energy Dispersive X-Ray of the extracted salts.

It is clearly seen that the chemical constituents of salt precipitated at pH10.5 contains a large amount of calcium salt and small amount of other elements as can be seen from figure (2), while the main element of precipitated salt at 11.5 is magnesium element as can be seen from figure (3). The magnesium salts burned in muffle furnace at $650{ }^{0} \mathrm{C}$ to produce magnesium oxide with a concentration of $90 \%$. The above-mentioned magnesium oxide was used to reduce fuel pollutants such as $\mathrm{Na}, \mathrm{V}, \mathrm{S}$, wax and asphaltene. The effect of $\mathrm{MgO}$ was also confirmed in the laboratory for the maximum reduction of heavy fuel pollutants. Also the rate of precipitation of magnesium oxide in suspended solution using gelatin as suspending agent with different concentration of gelatin was determined by using graduated cylinder. The distance of precipitation with time was measured visually. The 126 
Journal of Environmental Sciences (JES)

Institute of Environmental Studies and Research, Ain Shams University

Mahmoud, Al-Shaymaa et al.

largest time of precipitation of magnesium oxide in gelatin, solution was at 10 $\%$ gelatin solution. This suspended solution was taken into consideration in all prepared magnesium oxide suspension.

Rate of precipitation of suspended Magnesium oxide: The precipitation rate of extracted magnesium oxide was determined by the distance of precipitation salt in a graduated cylinder of $100 \mathrm{ml}$ value and measure the distance with respect to time (Sylvester et al, 2014).

Figures $(4 \& 5)$ show that the rate of precipitation depends on the concentration of gelatin, so that the rate of precipitation decreases with increase the concentration of gelatin. When the magnesium oxide suspended in different concentrations of gelatin $(0,2,4,6,8$, and $10 \%)$ the concentration of $2 \%$ gelatin showed the highest precipitation rate. Also the concentration of $10 \%$ has the lowest precipitation rate as can be seen from figures. This means that as the concentration of gelatin increase the suspension stability of magnesium oxide increase and the precipitation rate decrease as soon as, this concentration of gelatin does not affect the physical properties of the heavy fuel oil such as viscosity. 


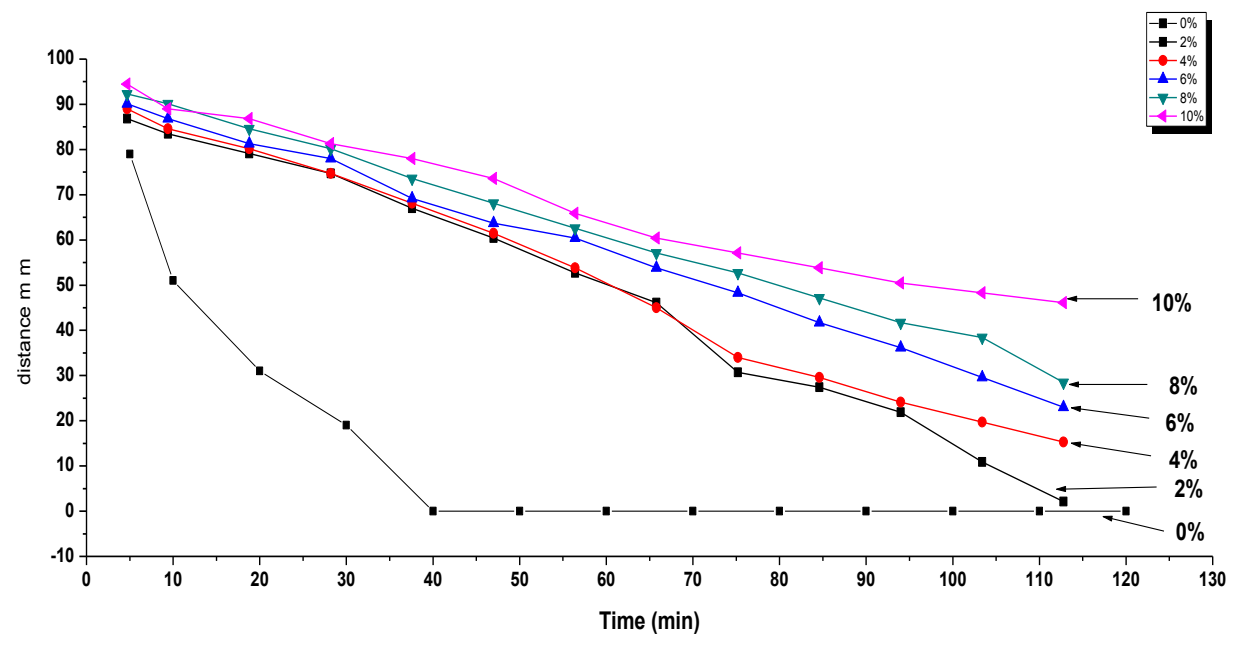

Figure (4): Sedimentation Time For suspended MgO

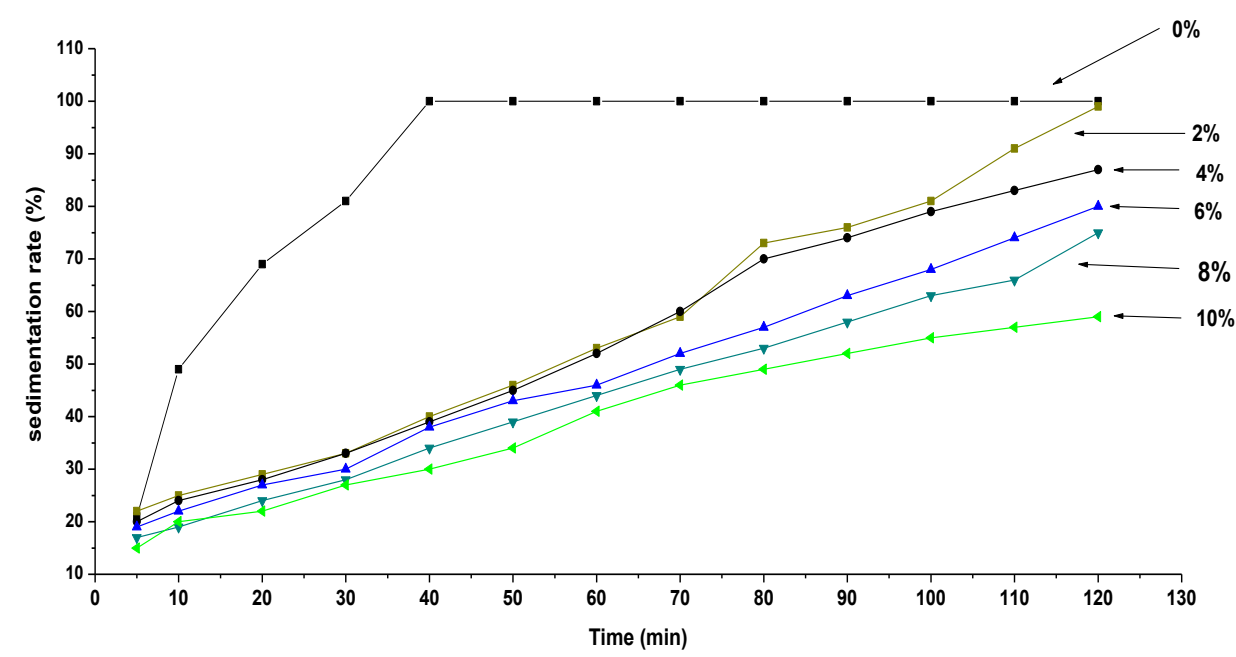

Figure (5): Sedimentation rate \% 
Effect of added magnesium (MgO) on the properties of heavy fuel oil: Effect of added magnesium (MgO) on the $\mathrm{pH}$ of combustion product (ashes and fly ash): The effect of addition of $(\mathrm{MgO})$ on the $\mathrm{pH}$ of the combustion products of examined heavy fuel oil was studied; Figure (6) shows the increasing of $\mathrm{pH}$ of combustion products from burning heavy fuel oil by using different doses of $(\mathrm{MgO})$.

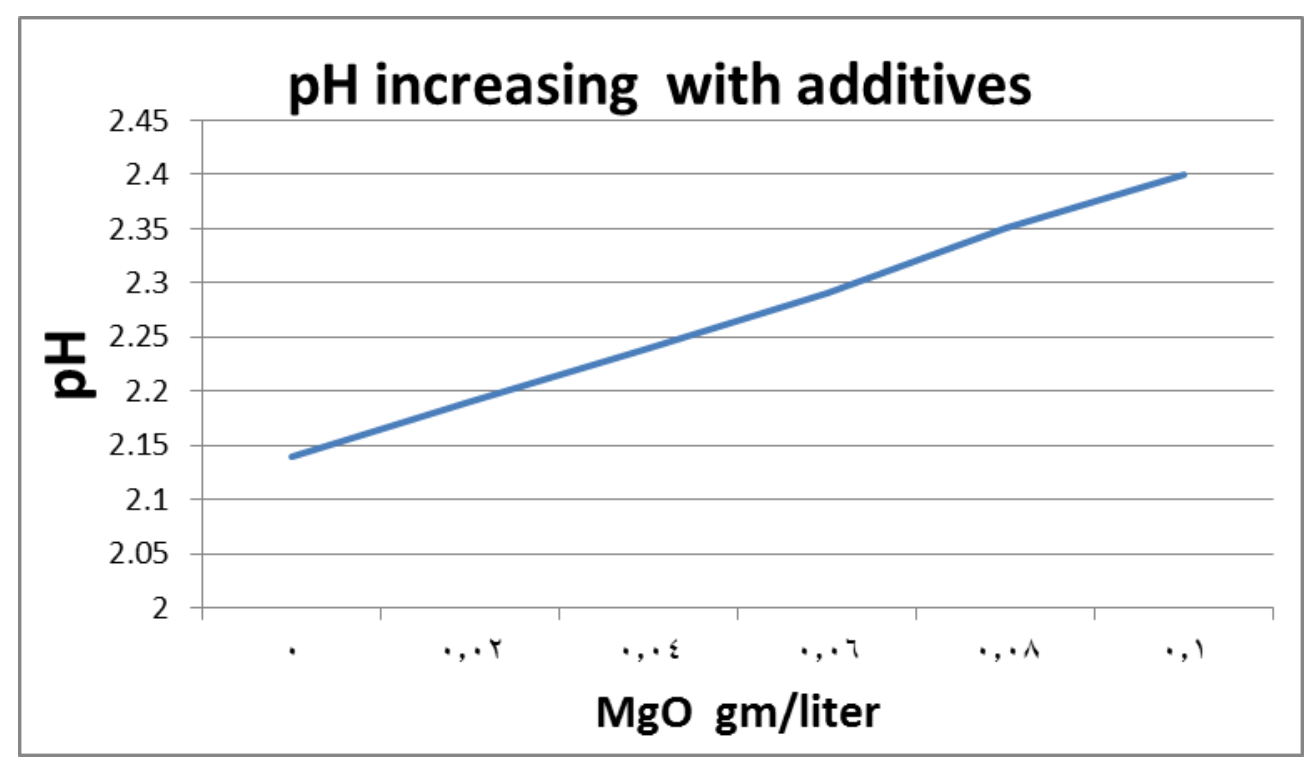

Figure (6): Effect of addition of $(\mathrm{MgO})$ on the $\mathrm{pH}$ of combustion products

As can be seen from the curve, increasing of the dose of magnesium oxide will increase the $\mathrm{pH}$ of combustion products -beginning from 2.19 and reaching to 2.35. It is well known fact that as the $\mathrm{pH}$ of combustion product of heavy fuel oil increase the effect of these ashes on the metal of boiler will be neglected and reducing of bad effects on the environment. 
Journal of Environmental Sciences (JES)

Institute of Environmental Studies and Research, Ain Shams University

Mahmoud, Al-Shaymaa et al.

\section{Effect of added magnesium oxide (MgO) on the removing of SOx gases of}

combustion product: The effect of extracted magnesium oxide $(\mathrm{MgO})$ on the free sulfuric acid produced from combustion of heavy fuel oil (Mazout) was studied:

Figure (7) shows the percentage reduction of free sulfuric acid produced from burning heavy fuel oil by using different doses of $(\mathrm{MgO})$ and this agree with figure( 6) because of the well-known fact $\mathrm{pH}$ increase when acid concentration decrease. The following equation confirmed the reaction of $(\mathrm{MgO})$ with $\mathrm{SO}_{2}$ as combustion product leads to form sulfuric acid.

$4 \mathrm{MgO}+4 \mathrm{SO}_{2} \rightarrow 3 \mathrm{MgSO}_{4} \ldots \ldots$

Figure (7) shows that the increase of magnesium oxide leading to decrease the amount of free sulfuric acid. 
Mahmoud, Al-Shaymaa et al.

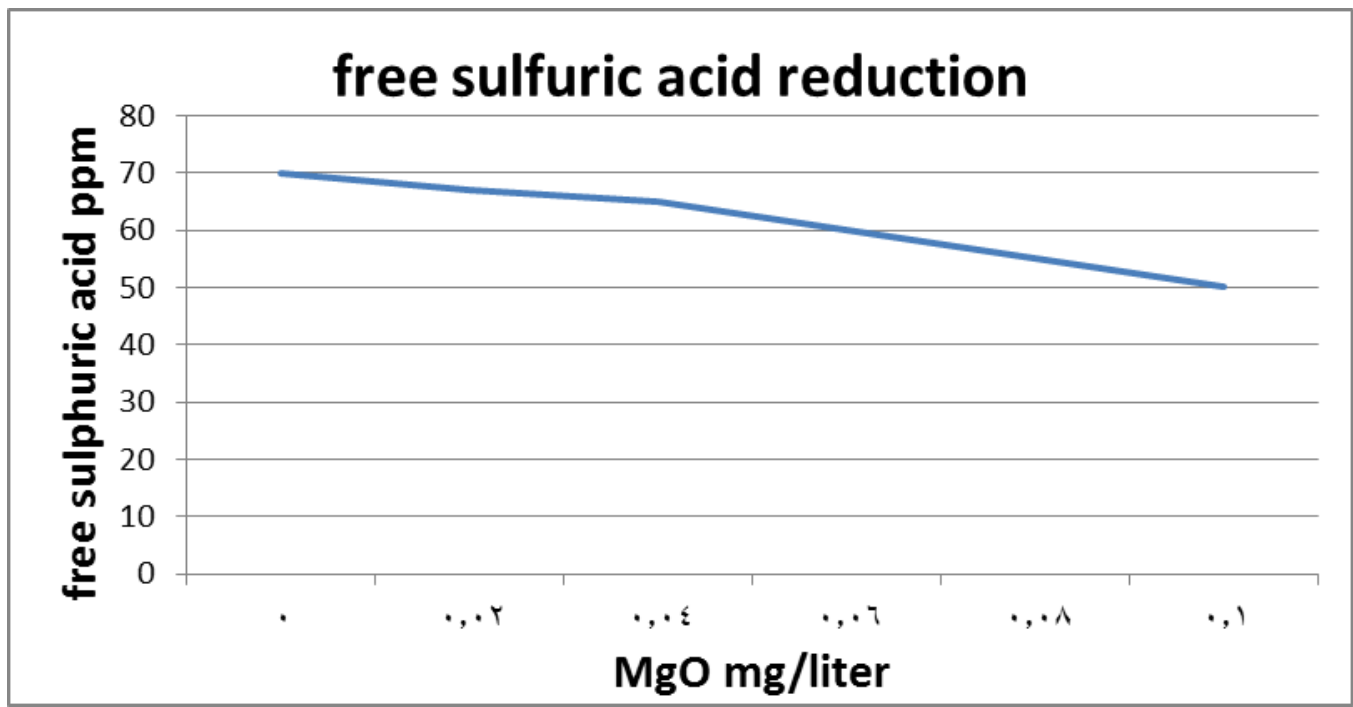

Figure (7): Effect of addition of $(\mathrm{MgO})$ on the removing of $\mathrm{SOx}$ gases of combustion product.

As can be seen from the curve, increasing the dose of magnesium oxide will reduce larger amount of free sulfuric acid beginning from $67 \mathrm{ppm}$ and reaching to $50 \mathrm{ppm}$ with percentage reduction of $28 \%$, these results compared with the certified used fuel additives in shoubra elkheima power plant (FS-2940) the used give reduction of free sulfuric acid with $31 \%$ in the laboratory tests.

Effect of added magnesium oxide on the specification of used heavy fuel oil (Mazout): A collective table was made to compare the specification of treated and untreated heavy fuel oil. 
Table (2): Specification of heavy fuel oil with without magnesium oxide as additive

\begin{tabular}{|c|c|c|}
\hline Test & Un treated heavy fuel oil & Treated heavy fuel oil \\
\hline \hline Ash content mass (\%) & 0.041 & 0.031 \\
\hline Carbon residue Mass (\%) & 4.6 & 4.45 \\
\hline Asphaltenes, $\mathrm{m} / \mathrm{m}(\%)$ & 2,2 & 2 \\
\hline Sulfur (\%) & 1.6 & 1.2 \\
\hline Vanadium ( ppm) & 47 & 38 \\
\hline Sodium (ppm) & 84 & 74 \\
\hline Gross Calorific value Kcal/g & 10597 & 10505 \\
\hline Net Calorific value Kcal/g & 10005 & 9938 \\
\hline Flash point ( Closed) ${ }^{0} \mathrm{C}$ & 92.1 & 103.2 \\
\hline \hline
\end{tabular}

According to table (2) the change of specification ash content, carbon residue, asphaltenes, sodium, vanadium and sulfur of fuel was compared with and without magnesium oxide as fuel additive, it show slightly change when using magnesium oxide as fuel additives.

\section{Determination of emission produced from burning of treated and} untreated heavy fuel oil at 250, 280 and $180 \mathrm{MW} / \mathrm{H}$ : The magnesium base fuel additives cause significant improvement of the combustion characteristics of local low-quality fuel approaching the combustion characteristics of the high-quality imported fuel. Also reduced $\mathrm{SO}_{3}$ and controlled acid smut emission, Emissions of sulfur dioxide and nitrogen oxides lowered after using the fuel additives which could lead to reduce the dew point temperature and thus improves the thermal efficiency of the 
Journal of Environmental Sciences (JES)

Institute of Environmental Studies and Research, Ain Shams University

Mahmoud, Al-Shaymaa et al.

equipment which will use these additives in addition to the yield positive impact on the environmental impact assessment (Emara et al, 2016). Figure (8) shows the comparison between emissions of NOx, SOx, and CO for Treated and un treated heavy fuel oil (Mazout) in Shoubra El-kheima power station When using heavy fuel oil with approximately the same sulphur content, chemical and physical properties at the same load $(250 \mathrm{MW} / \mathrm{H})$. A significant change in the flue gases was observed. As can be seen from figure (8). With respect to SOx the value was reduced from 3617 to $2523 \mathrm{mg} / \mathrm{m}^{3}$. Also NOx reduced from 312 to 210 . The carbon monoxide slightly reduced from 40.8 to $40 \mathrm{mg} / \mathrm{m}^{3}$, Thus according to the above mentioned there is a reduction in the concentration of NOx by $29 \%$ and SOx by $30 \%$ produced from burning treated fuel oil in Shoubra El-kheima power plant. The fuel additives shows enhancement in the complete combustion of heavy fuel oil so the carbon monoxide produced from un complete combustion was decreased, also the required air for complete combustion was decreased and subsequently the emitted nitrogen oxides was decreased, also using of fuel additives has been reported to decrease the sox emission because of the reaction between sox and magnesium oxide. 


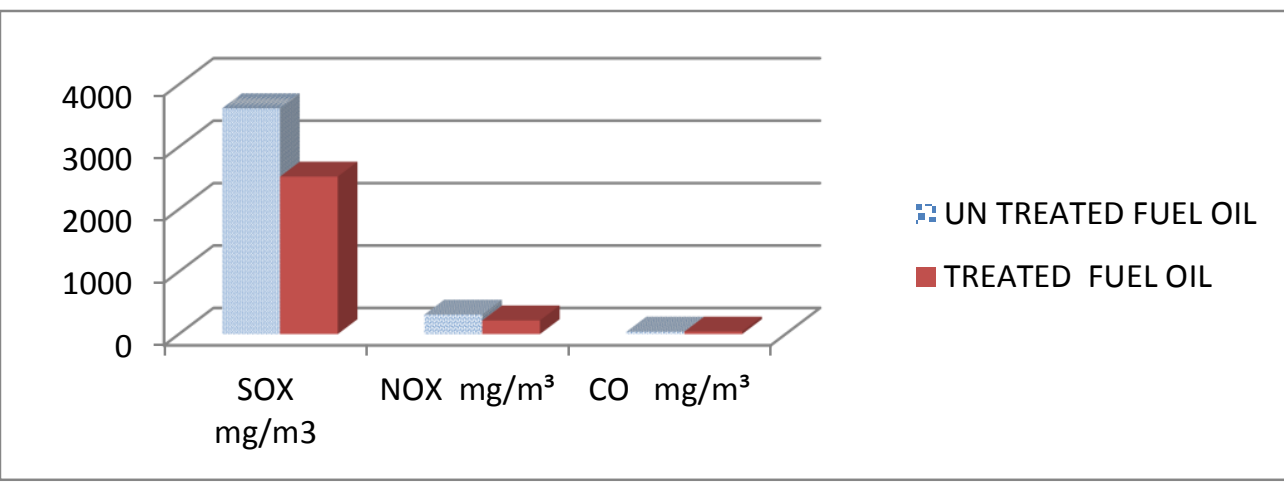

Figure (8): Flue gas analysis of treated and untreated heavy fuel oil at 250 $\mathrm{MW} / \mathrm{H}$

Figure (9) shows Comparison between emissions of NOx, SOx, and CO for Treated fuel oil \& un treated fuel oil burned in Shoubra El-kheima power plant when using heavy fuel oil with approximately the same sulphur content, chemical and physical properties at load of $(280 \mathrm{MW} / \mathrm{H})$.

As can be seen from figure (9), With respect to SOx the value was reduced from 3685 to $3083 \mathrm{mg} / \mathrm{m}^{3}$. Also NOx reduced from 400 to 346 . The carbon monoxide was reduced from 30 to $19 \mathrm{mg} / \mathrm{m}^{3}$. Also there is a reduction in the concentration of SOx by $16 \%$ and $\mathrm{CO}$ by $36 \%$ and $13.5 \%$ for NOx in the flue gases produced from burning of treated fuel Oil with respect to un treated one at $280 \mathrm{MW} / \mathrm{H}$. 
Mahmoud, Al-Shaymaa et al.

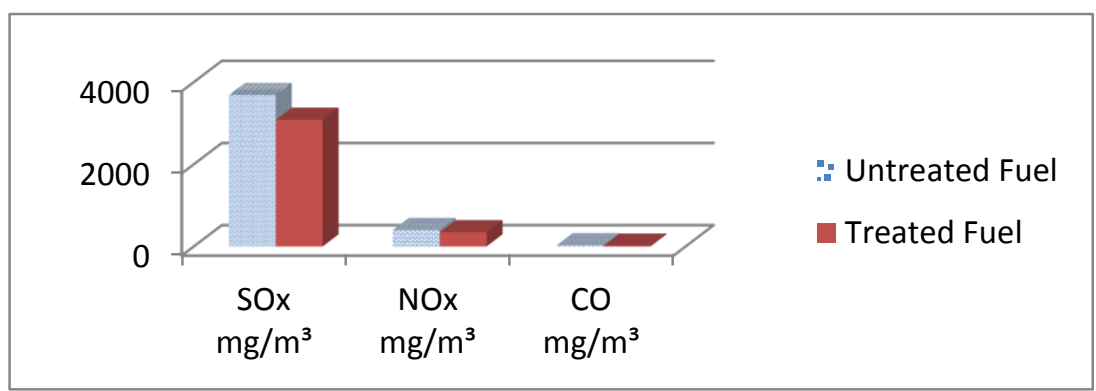

Figure (9): Flue gas analysis of treated and untreated heavy fuel oil at 280MW/H

Figure (10) shows a comparison between gas emissions of NOx, SOx, and CO for treated and untreated fuel oil burned in Shoubra El-kheima power plant when using heavy fuel oil with approximately the same sulphur content, chemical and physical properties at the same number of mazout burners (6 burners) and (10 NG burners) at the same load180MW/H.

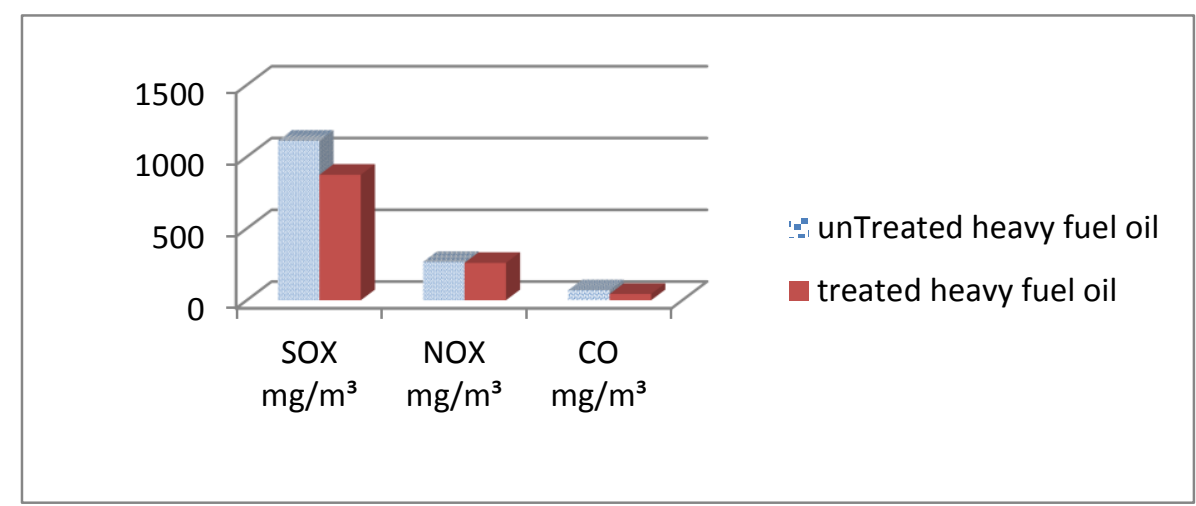

Figure (10): Flue gas comparison of treated and untreated heavy fuel oil at 180MW/H 
Journal of Environmental Sciences (JES)

Institute of Environmental Studies and Research, Ain Shams University

Mahmoud, Al-Shaymaa et al.

Figure (10) shows the variation of flue gases SOx , NOx and CO when burning mixed fuel natural gas, treated and untreated heavy fuel oil at 6 burners mazout and (10) NG burners at 180MW/H . As can be seen from Figure (10) there is a reduction in the concentration of $\mathrm{CO}$ by $37 \%$, SOx by $21 \%$ and $2.6 \%$ for NOx produced from burning treated fuel oil in Shoubra El-kheima power plant.

\section{CONCLUSION}

Extraction of magnesium oxide salt from cation regeneration wastewater (CRWW) and using of extracted magnesium oxide as a fuel additive for heavy fuel oil (mazout) to reduce some contaminants such as free sulfuric acid and flue gases in combustion products produced from combustion of heavy fuel oil in laboratory was studied. By using this salt the amount of sulfur in heavy fuel oil reduced from $1.6 \mathrm{ppm}$ to $1.2 \mathrm{ppm}$ with a percent reduction by $25 \%$, for vanadium the reduction in its value is from $47 \%$ to 38 $\%$ with percentage reduction of $9.1 \%$, the value of sodium reduced from 84 ppm to $74 \mathrm{ppm}$ with percentage reduction of 11.9 , also the value of free sulfuric acid is reduced $67 \mathrm{ppm}$ to 50 with percentage reduction of $28 \%$ and this is an indication for the reduction of $\mathrm{SO}_{\mathrm{X}}$ emission . in addition It was show that the physical properties of fuel slightly changed when using magnesium oxide as fuel additives. The observation of emission values for fuel additives shows reduction in the harmful emission of SOx, NOx and CO. Nevertheless, the fuel additives shows enhancement in the complete 136 
Journal of Environmental Sciences (JES)

Institute of Environmental Studies and Research, Ain Shams University

Mahmoud, Al-Shaymaa et al.

combustion of heavy fuel oil so the required air for complete combustion was decreased and subsequently the emitted nitrogen oxides will decrease.

\section{REFRENCES}

Akaboshi, T.; Kaneko, N. Sakuma and Sugiyama (1987): Recovery of ammonium metavanadate from petroleum-combustion residues, Jpn. Kokai Tokkio Koho JP 62, 298,316.

Alvarez, CE. Fernandez, M. Perez, N. Iglesias and E. Snelling (1993): Effect of fly ash from a fuel oil power station on heavy metal content of wild plants At Tenrrife Island, the Canadian Archipelago, Spain, J. environ. SCI. health A28, no. 2, 269-283.

Atsonios, K. Panopoulos, P. Grammelis, and E. Kakaras (2016): Exergetic comparison of $\mathrm{CO}_{2}$ capture techniques from solid fossil fuel power plants. International Journal of Greenhouse Gas Control 45: 106.

Bureau (2001): South African of Standards code of practice (2001) 089 Part II.

Chmielewski, AG. Urbanski and TS. Migdal (1997): Separation technologies for metals recovery from industrial wastes, $\mathrm{j}$. Hydrometallurgy 45 , 333-334.

Edwards CR (1991): The recovery of metal values from process residues, J. Mineral. 43, 32.

Emara, A. (2016): Effect of chemical fuel additives on liquid fuel saving, and emissions for heavy fuel oil. International Mechanical Engineering Congress \& Exposition IMECE 2016 November 1117, 2016, Phoenix, Arizona, USA https://doi.org: 10.1115/IMECE2016-65717. 
Energy Information Administration (EIA) (2013): International Energy Outlook 2013. Electricity. Report Number: DOE/EIA0484(2013). http://www.eia.gov/ forecasts /archive / ieo13/electricity.cfm (accessed 17.02.16).

Geankoplis, Ch., J. (1993): Transport Process and unit operations, Printice Hall international 'Inc., university of Minnesota., $3^{\text {rd }}$ edition, $\mathrm{P}$ 144, P 725.

El-Sayed G.O., A.I. Hafez ,H.M. Zahr El-Deen and F. Salah El-Din (2016): Extraction of Calcium and magnesium ions from WaterTreatment-Plant Sludge for Reusing in industrial water Treatment" International Journal of Advanced Scientific and Technical Research., volume 5, issue 6, pages 491-510.

Gridlogics Technologies Pvt. Ltd. (2010): 'Technology Insight Report Fuel Additives. Patent insight Pro $^{\mathrm{TM}}$

Grisafi, F. Brucato, and Rizzuti (1998): Solid-liquid transfer coefficients in gas-liquid-solid system agitated vessels, The Canadian journal of chemical engineering, vol. 76, issue 3, pages 446-455, June.

E.M, Khalil, A.B. Farag, KH. EL-Nagar, A.I. Shehata and R.A ELaithy (2014): extraction of some calcium and magnesium salts from waste water of regeneration process in demineralization plant, alazhar bulletin of science volume 25 , issue 6 , pages 444-446

Khalil. A.I. Ahmed, Ashraf. I. Hafez, Taha M.A Razek and Ali. A. Maan (2020): Characterization of Power Plant Residue Using Various Spectroscopic Techniques for Recycling Valuable Metals", Journal of Waste and Biomass Valorization, 11, 4649-4665.

Khorasani, A. C. Mashreghi, M, and Yaghmaei, S. (2013): Study on biodegradation of Mazut by newly isolated strain Enterobacter cloacae BBRC10061: improving and kinetic investigation, Iranian Journal of Environmental Health Sciences \& Engineering, Vol. $10: 2$, 
Kim DC., Nho NS, Woo JK, Kim JH, Lee YS. (2008): A study on the reduction of particulate emission using oil soluble organometallic compounds as combustion improver for heavy fuel oil. J Korean Soc Atmos Environ;24(1):55-62 [in Korean].

Lakshmanan VI, Melnbardis and D. Geisler (1989): Process for treatment of fly ash , no. U. S. patent No. 7097984.

Leavenspile (1999): Chemical Reaction Engineering, John-Wiley and Sons ind., $3^{\text {rd }}$ edition, P 582 ، New York .

Luis et al., (2000): "Vanadium recovery by leaching in spent catalysts for sulfuric acid production", Science and technology. Vol. 8, No. 16, P. 85-90 .

NGSA (2012): Natural Gas Supply Association. 〈http://www. naturalgas. org ; [ [accessed 30.10.12].

Othman, H.B. Mat. and Yuliusman (1999): Selective nickel recovery from spent Catalyst ."World Engineering Congress and Exhibition (WEC 99) ; Kuala Lampur, July 19-22..

Prelec Zmagoslav, Mrakovcic Tomislav and Dragicevic Viktor. (2013): Performance study of fuel oil additives in real power plant operating conditions. Fuel Process Technol; 110:176-83.

Stas, J. Dahduh, A. and Al-chayah (2007): Recovery of vanadium, nickel and molybdenum from fly ash of heavy oil-fired electrical power station, chemical Engineering, 51/2, 67-70, Syria .

Sylvester O. Eraga, Magnus A. Iwuagwu and Michael U Adikwu (2014): Evaluation of the Suspending Properties of the Co-precipitate of Irvingia gabonesis Gum and Gelatin. Tropical Journal of Pharmaceutical Research; 13 (6): 843-848.

Teir and Sebastian. (2002): Basics of Steam Generation. Helsinki: Energy Engineering and Environmental Protection Publications. 
Journal of Environmental Sciences (JES)

Institute of Environmental Studies and Research, Ain Shams University

Mahmoud, Al-Shaymaa et al.

Thermal Power Plant Classification (2016): Retrieved May 18, 2016, from http://thermal-powerplant.blogspot.my/2010/05/thermal-powerplanclassification.html.

Tsai, S.-L., Tsai and M.-S., (1998): A study of the extraction of vanadium and nickel in oil-fired fly ash," conservation and recycling, 22, pp. 163-176, China.

Tsuboi, I. Kasai ,S. Kunugita and E. Komosawa I. (1991): Recovery of gallium and vanadium from coal fly ash, J. Chem. Eng. 24, 15-20

Van de Wale (1989): Concentrated suspention of aqueous magnessium oxide U. S Patent 4,834,957.

Vitolo ,S. Seggiani, M.Filpi ,S. Brocchini (2000): Recovery of vanadium from heavy oil and Orimulsion fly ashes. j. Hydrometallurgy 57, 141-149.

Whigham W. (1965): New in extraction: Vanadium from petroleum", Chem. Eng.7 2, no. 5, 64-66.

Wood, David, A. Chikezie Nwaoha and Brian F. Towler (2000): Gas-toliquids (GTL) A review of an industry offering several routes for monetizing natural gas. Journal of Natural Gas Science and Engineering 9: 196-208.

Youngs ,W .D. Rutzke, M. Gutenmann and WH. Lisk (1993): Nickel and vanadiumin foliage in the vicinity of oil fired power plant, Chemosphere 27،no. 7, 1269-1272. 


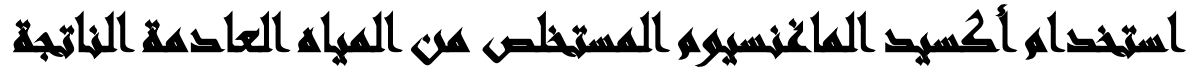

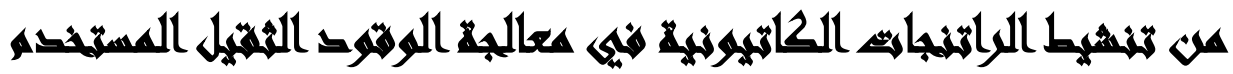

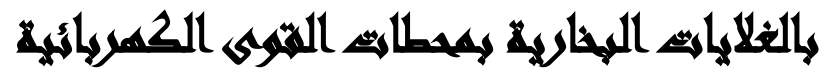

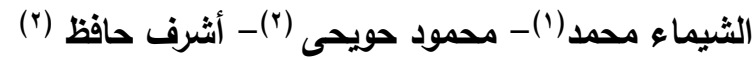

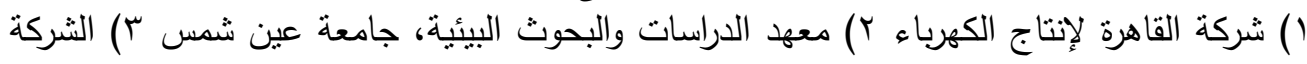
القابضة لكهرباء مصر الهرة

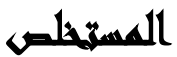

يعتبر اكسيد الماغنسيوم من أكثر المواد المستخدمة كإضافات وقود لمعالجة المازوت ويتتاول

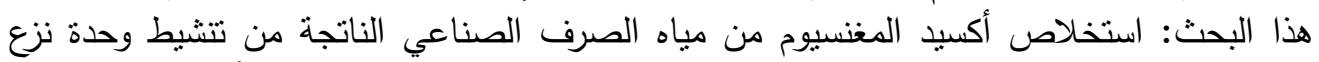
الكاتيونات. تم تحضير محلول من الجيلاتين به عدة تركيزات مختلفة من أكسيد الماغنسيوم المستخلص لعمل محلول معلق من أكسيد الماغنسيوم واستخدامه في معالجة الونين الوقودة.

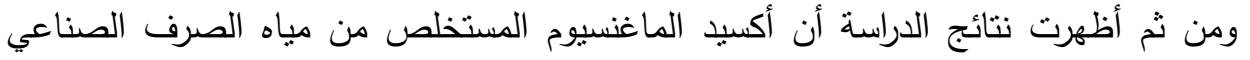

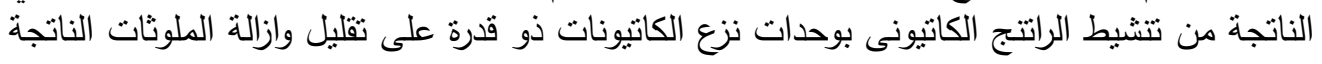

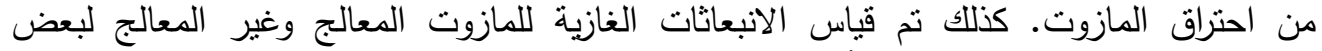

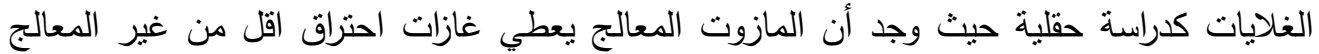

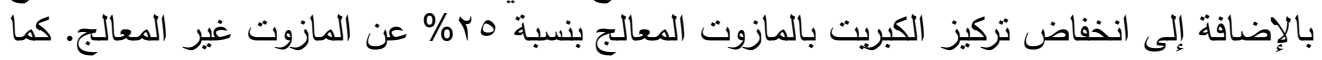

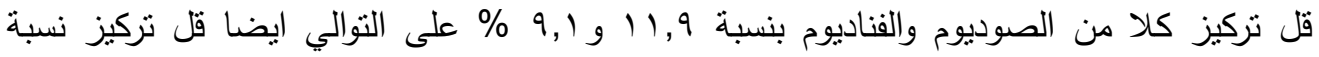

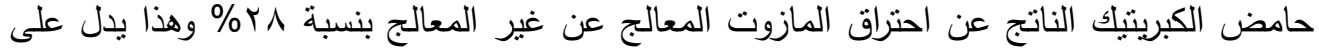

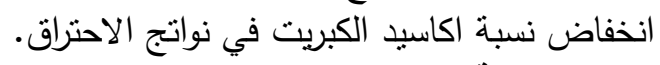
الكلمات الدالة: الانبعاثات، اضافات الوقود، اكسيد الاحترات الماغنسيوم، الصوديوم، الفناديوم، الكبريت. 